\title{
COVID-19 ve Bakteriyel Ko-Infeksiyon: Fusobacterium Bakteriyemisi
}

\section{COVID-19 and Bacterial Co-Infection: Fusobacterium Bacteremia}

\begin{abstract}
Ahmet Mert CAVNAR'(ID), İrem AKDEMIR KALKAN'(IiD), Mehmet Serhat BiRENGEL'(ID), Ebru EVREN²(ID),
\end{abstract} Zeynep Ceren KARAHAN²(ID)

\footnotetext{
${ }^{1}$ Ankara Üniversitesi Tıp Fakültesi, İnfeksiyon Hastalıkları ve Klinik Mikrobiyoloji Anabilim Dalı, Ankara, Türkiye

2 Ankara Üniversitesi Tıp Fakültesi, Tıbbi Mikrobiyoloji Anabilim Dalı, ỉbni Sina Hastanesi Merkez Mikrobiyoloji Laboratuvarı, Ankara, Türkiye
}

Makale atifi: Cavnar AM, Akdemir Kalkan i, Birengel MS, Evren E, Karahan ZC. COVID-19 ve bakteriyel ko-infeksiyon: Fusobacterium bakteriyemisi. FLORA 2021;26(2):334-7.

\section{ÖZ}

Koronavirüs Hastalığı 2019 (COVID-19) ilk olarak Çin'in Vuhan Wuhan şehrinde Aralık 2019'da görülen ve sonrasında pandemiye sebep olarak tüm dünyayı etkisi altına alan viral infeksiyon hastalığıdır. Hastalı̆ıın seyri belirtisiz olabileceği gibi ateş, öksürük, nefes darlığı, halsizlik, baş ağrısı, boğaz ağrısı gibi semptomlar görülebilir. Bazı COVID-19 hastalarında çeşitli bakteriyel infeksiyonlar sürece eşlik edebilir. Bu olguda COVID-19 tanısı alan bir hastada eşlik eden Fusobacterium nucleatum bakteriyemisi incelenmiştir.

Anahtar Kelimeler: COVID-19; Fusobacterium; Anaerob; Ko-infeksiyon

\section{ABSTRACT \\ COVID-19 and Bacterial Co-Infection: Fusobacterium bacteremia}

Ahmet Mert CAVNAR', İrem AKDEMIR KALKAN', Mehmet Serhat BIRENGEL', Ebru EVREN², Zeynep Ceren KARAHAN ${ }^{2}$

\footnotetext{
${ }^{1}$ Department of Infectious Diseases and Clinical Microbiology, Ankara University Faculty of Medicine, Ankara, Turkey

2 Department of Medical Microbiology, Ankara University Faculty of Medicine, ibni Sina Hospital Central Microbiology Laboratory, Ankara, Turkey
}

Coronavirus Disease 2019 (COVID-19) is a viral infection first seen in Wuhan, China, in December 2019 and then affected the whole world by causing a pandemic. The disease may be asymptomatic, and symptoms such as fever, cough, shortness of breath, weakness, headache, and sore throat can be seen. Various bacterial infections may accompany the process in some COVID-19 patients. In this case, accompanying Fusobacterium nucleatum bacteremia in a patient diagnosed with COVID-19 was examined.

Key Words: COVID-19; Fusobacterium; Anaerob; Co-infection

${ }^{\circledR}$ Telif Hakkı 2021 Flora. Makale metnine www.floradergisi.org web adresinden ulașılabilir 


\section{GiRiş}

Fusobacterium türleri, Bacteroidacea ailesinden sporsuz, gram-negatif, anaerob basillerdir. Fusobacterium cinsi içinde en sik görülen tür Fusobacterium nucleatum'dur. F. nucleatum simbiyotik, fırsatç 1 bir bakteridir. Oral florada ve gastrointestinal sistem florasında bulunabilir. Yakın zamanlı bazı yayınlarda $F$. nucleatum ve kolorektal kanser arasında ilișki olduğunu düșündüren bulgulara rastlanmıstır ${ }^{[1]}$.

F. nucleatum'un sebep olduğu klinik durumlar periodontal infeksiyonlar, tonsillit, apandisit, endokardit, solunum yolu infeksiyonları, beyin apsesi, karaciğer apsesi, osteomyelit, koryoamniyonit gibi pek cok sistemi etkileyebilen infeksiyon tablolarıdır ${ }^{[2]}$.

Fusobacterium infeksiyonları genellikle beta-laktamlara duyarl olup penilisin veya sefalosporin grubu antibiyotiklerle tedavi edilmektedir. Bazı izolatlar, beta-laktamaz enzimine sahip olduğundan bunlara karșı anaerobik etkinliği olan metronidazol veya klindamisin tedavide düșünülebilir ${ }^{[3]}$.

Lemierre Sendromu olarak bilinen internal juguler venin tromboflebiti esas olarak $F$. necrophorum'a bağlı gelissse de F. nucleatum da bu kliniğe sebep olabilmektedir ${ }^{[4]}$.

$\mathrm{Bu}$ yazıda COVID-19 tanısı ile izlenirken aynı zamanda tonsillit de gelișmis olan hastada kan kültürü üremesi ile tespit edilen $F$. nucleatum bakteriyemisi değerlendirilmiștir.

\section{OLGU SUNUMU}

Yirmi altı yașında kadın hasta, tıbbi geçmișinde bilinen astım ve tiroid nodülü olup, üc gündür olan boğaz ağrısı, yutma güçlüğü, iștahsızlık, mide bulantısı ve ara ara olan kuru öksürük sikayetleriyle acil servise bassvurdu. Ek olarak iki gündür üșüme titremeyle gelen ve terlemeyle düsen, $39^{\circ} \mathrm{C}$ yi bulan, günde 2-3 kere olan ve oral parasetamol ile düssen ateși mevcuttu. Aktif is yașamina devam eden hastanın COVID-19 hastası ile temas1 yoktu. Hasta ile teması yoktu, aktif is yașamına devam eden bir hastayd. Acil serviste bașvurusundaki vital bulgularında vücut sıcaklığ $38.9^{\circ} \mathrm{C}$, tansiyon arteriyeli $123 / 87 \mathrm{mmHg}$, oksijen saturasyonu oda havasında \%98, nabız: 85/dk, ritmik olarak saptanmıștı. Orofarenks muayenesinde farenks- te hiperemi ve tonsillerde hipertrofik görünüm mevcuttu. Solunum sistemi muayenesinde her iki hemitoraks solunuma eșit katılıyordu, akciğerlerde patolojik sese rastlanmamıștı. Hastadan COVID-19 için nasal ve orofarengeal sürüntü örneği ve ateși olduğu süreçte 2 set kan kültürü alındı. Hastanın SARS-CoV-2 polimeraz zincir reaksiyon (PZR) sonucu pozitif saptand ve COVID-19 tanis1 ile hastaneye yatırıldı. Yapılan kontrastsız düșük doz toraks bilgisayarlı tomografi görüntülemede pnömoni bulgusu saptanmadi, ek patoloji de görülmedi. Hastaneye yatısında CRP: $211 \mathrm{mg} / \mathrm{L}$ (05), prokalsitonin: $1.53 \mathrm{ng} / \mathrm{mL}(0.05-0.5$, lokalize infeksiyon ve düșük sepsis riski: $0.5-2$, sepsis riski: $>2$ ciddi sepsis ve septik sok riski), lökosit say1s1: $10.4 \times 10^{9} / \mathrm{L}\left(4.5-11 \times 10^{9}\right)$ lenfosit sayıs1: $0.86 \times 10^{9} / \mathrm{L}\left(1.5-4 \times 10^{9}\right)$ kreatinin: $0.85 \mathrm{mg} / \mathrm{dL}$ (0.67-1.17), BUN: $11 \mathrm{mg} / \mathrm{dL}$ (8-23), AST: 34 U/L (0-40), ALT: 19 U/L (0-40), D-dimer: 322 $\mathrm{ng} / \mathrm{mL}$ (0-243) olarak bulundu.

Hastaya, COVID-19 tanısı ile güncel TC Sağlık Bakanlığı COVID-19 (SARS-CoV-2 infeksiyonu) Erișkin Hasta Tedavisi Rehberine göre, favipravir $2 \times 1600 \mathrm{mg}$ ilk gün yükleme ve $2 \times 600 \mathrm{mg} /$ gün idame seklinde oral antiviral tedavi ve enoksaparin $0.4 \mathrm{~mL}$ (4000 anti-Xa IU)/gün subkutan bașland. Hastanın muayenesinde tonsillerindeki kriptik görünüm nedeniyle ampisilin-sulbaktam $4 \times 1$ gr/gün, iv. tedaviye eklendi.

Hastanın takibinde yatıșının ikinci gününde bir önceki gün alınarak Ankara Üniversitesi Merkez Mikrobiyoloji Laboratuvarına gönderilen kan kültürleri için yapilan incelemede anaerop siselerinde 17. ve 20. saatlerde sinyal alınması üzerine, anaerop kan kültür sisselerinden yayma hazırlanarak Gram boyama yapıldı, es zamanlı olarak örneklerin Kanlı agar $(\mathrm{BD}, \mathrm{ABD})$, MacConkey agar (BD, $\mathrm{ABD}$ ), Cikolata agar ve Brucella Kanlı agar (BD, ABD) ekimleri yapıldı. Kanlı agar, MacConkey agar plakları $37^{\circ} \mathrm{C}$ 'de aerobik sartlarda, Cikolata agar plakları ise $37^{\circ} \mathrm{C}$ 'de $\% 5$ karbondioksitli ortamda 24-48 saat, Brusella kanlı agar plakları anaerobik ortamda 72 saat inkübe edildi. Aerobik sartlarda inkübe edilen plakların 24 saat sonunda üreme kontrolleri yapıldı, üreme gözlenmeyen plakların inkübasyonu 48 saate uzatıldı. Örneğin Gram boyamasında ince fuziform sekilli gram-negatif basiller görülmesi üzerine hemen telefon 
ile kliniğe bilgi verildi. 24-48 saatlik inkübasyon sonrası aerop koșullarda inkübe edilen kültuirlerde üreme olmazken, 72 saat sonra anaerobik kültuirde üreme tespit edildi. Üreyen mikroorganizmalar Matrix Assisted Laser Desorption Ionization-Time of Flight Mass Spektrometry (MALDI-TOF MSBruker Daltonics, Almanya) ile F. nucleatum olarak (skor $\geq 2$ ) tiplendirildi ve bu sekilde raporland.

$\mathrm{Bu}$ üreme üzerine, hastada olası Lemierre Sendromu ön tanısı ile Kulak Burun Boğaz Hastalıkları bölümünden konsültasyonu istendi. Cekilen boyun bilgisayarlı tomografi görüntülemede tonsiller mukozada kontrastlanma izlendi. İnflamasyona ikincil olarak değerlendirildi. Boyunda patolojik lenf nodu veya apse koleksiyonu saptanmad. Vasküler yapilarda dolum defekti saptanmadi. Bașlanmış olan antibiyotik tedavisi sonrası klinik ve laboratuvar yanıtı alınmıs olan hastanın tedavisine ayn sekilde devam edildi. F. nucleatum üremesi sonrasında, mevcut kliniğin olası bir yalanc1 pozitif SARS-CoV-2 PCR sonucundan kaynaklanmıs olabilecek izole bir anaerobik infeksiyon veya COVID-19'e esslik eden bakteriyemi ile seyreden bir ko-infeksiyon ayırımı yapmak amacı ile hastadan 2. bir PCR örneği alındı; sonuç yine pozitif olarak saptand. Hastanın intravenöz antibiyotik tedavisi 10 güne, antiviral tedavisi 5 güne tamamlanarak sifa ile taburcu edildi. Taburculuk öncesi bakılan CRP değeri $9 \mathrm{mg} / \mathrm{L}$, lökosit say1s1: $4.8 \times 10^{9} / \mathrm{L}$, lenfosit say1s1: $3.2 \times 10^{9} / \mathrm{L}$ ve D-dimer: $311 \mathrm{ng} / \mathrm{mL}$ olarak görüldü.

\section{TARTIȘMA}

Fusobacterium türlerine bağlı gelișen bakteriyemiler nadir görülmekte olup, erișkinlerdeki tüm bakteriyemiler arasında \%1'den az olduğu, anaerobik bakteriyemiler arasında \%10'dan az olduğu düșünülmektedir. Özellikle hastane kaynaklı bakteriyemilerin ürogenital veya gastrointestinal sistemi ilgilendiren ișlemlerden sonra ortaya çkabileceği ve polimikrobiyal olabileceği akılda tutulmalıdır[5].

Hematolojik malignitesi olan hastalarda anaerobik bakteriyemilerin sıklığı son yıllarda artmıștır. Yapılan bir çalıșmada özellikle nötropenik ve oral mukoziti olan hematolojik maligniteli hastalarda $F$. nucleatum bakteriyemileri görülmüștür. Malignite dișinda diabetes mellitus, intestinal, pulmoner, hepatik ve jinekolojik hastalıklarda da orofarengeal, gastrointestinal, ürogenitel ve pulmoner kolonizas- yona sekonder F. nucleatum bakteriyemisi gelisebileceği bilinmektedir. Özellikle oral mukoziti olan immünsupresif bireylerde bakteriyemi süphesinde en az iki set kan kültürü alınması önem kazanmaktadir ${ }^{[6]}$.

COVID-19 penceresinden bakıldığında ise eșlik eden diğer infeksiyon etkenleriyle birliktelik COVID-19 seyrindeki mortalite ve morbidite cok önemlidir. Özellikle COVID-19 sebebiyle yoğun bakımda yatan hastalarda görülen bakteriyel ko-infeksiyonlar mortaliteyi arttırmaktadir ${ }^{[7]}$.

Salgının en bașindan bu yana COVID-19'a hem viral hem bakteriyel infeksiyonlarin ve hatta mantar infeksiyonlarının eșlik etmesiyle ilișkili klinik pek cok durum tanımlanmıstır ${ }^{[8]}$. Fusobacterium infeksiyonları açısından değerlendirildiğinde ise literatürde Belçika'dan bildirilen dört olguluk seri ilgi çekicidir. Bu seride COVID-19'a eșlik eden dört Fusobacterium infeksiyonu açıklanmıș olup bu olgularda Fusobacterium infeksiyonu gelișimi için herhangi bir risk faktörü tanımlanmamıștır. COVID-19 birlikteliği ile seyreden Fusobacterium birlikteliğinin dikkat çekici bir tablo olduğu vurgulanmıștır [9].

Yine literatürde ciddi seyirle ilerleyen bir pediatrik COVID-19'lu hastada Fusobacterium necrophorum'un izole edildiği Lemierre sendromu bildirilmiștir. Bu hastada tablonun septik sok ile seyredip oldukça gürültülü ilerlediği; uzun süreli antibiyoterapi ve antikoagülan tedavisi ile hastanın izlendiğinden bahsedilmiștir ${ }^{[10]}$.

Ülkemizde Fusobacterium infeksiyonuna ait yapılmıș çalıșmalar ve olgu bildirimleri bulunsa da bu olgu bilgimiz dahilinde, COVID-19 ile birlikteliği ilk kez bildirilen olgudur. Aynı zamanda dünya genelinde de su an için az sayıdaki bildirilmiş olgulardan biridir ${ }^{[9-11]}$.

COVID-19 seyrinde ates s1k görülen bir bulgu olup, ates nedeniyle hangi sıklıkla kan kültürü alınması gerektiği tartıșmaya açık bir konudur. Kesin tanılı olgularda ateș nedeni coğunlukla COVID-19'un kendisi olup, sekonder bakteriyel infeksiyon sıklığı yapılan calıșmalarda \%3-4 oranında bildirilmistir ve ampirik antibiyotik tedavisi de önerilmemektedir ${ }^{[12]}$. Sepulveda ve arkadașlarının yapmıș olduğu çalıșmada özellikle hangi durumlarda kültür alınması konusuna cevap 
aranmıs, COVID-19 hastalarında bekteriyeminin oldukça nadir olduğu vurgulanmıș ve kaynakların doğru kullanımının öneminin altı cizilmiștir ${ }^{[13]}$. Bizim olgumuzda hastanın gelișindeki muayene bulgularında tonsillerin hipertrofik olması ve de CRP değerinin oldukça yüksek olmasına rağmen, COVID-19'a bağlı akciğer parankim tutulumu olmaması ve beraberinde prokalsitonin yüksekliği de bulunması bakteriyel infeksiyon olasılığını akla getirdiği için kan kültürü alınmıștır. Bakteriyemi saptandığında da COVID-19 tanısından emin olabilmek için PCR testi tekrarlanarak COVID-19 tanısı konfirme edilmistir.

Sonuc olarak sik olmasa da COVID-19 ile takipli hastalarda sekonder bakteriyel infeksiyon gelișebileceği akılda tutulmalıdır ve bu açıdan detayl hikaye, klinik ve laboratuvar takipleri titizlikle yapılmalıdır. Özellikle etken izolasyonunu sağlayabilmek için doğru zamanda ve doğru sekilde kan kültürü alınması cok önemlidir. Fusobacterium infeksiyonlarının COVID-19 seyrindeki önemi bu konuda daha çok deneyim biriktikçe netlik kazanacak bir alandir.

\section{ÇIKAR ÇATIȘMASI}

Yazarlar bu makale ile ilgili herhangi bir çkar çatıșması bildirmemișlerdir.

\section{YAZAR KATKISI}

Anafikir/Planlama: IAK, MSB, AMC

Analiz/Yorum: EE, ZCK, MSB

Veri sağlama: EE, ZCK, AMC

Yazım: IAK, AMC, MSB ,EE, ZCK

Gözden Geçirme ve Düzeltme: MSB

Onaylama: MSB

\section{KAYNAKLAR}

1. Brennan CA, Garrett WS. Fusobacterium nucleatum - symbiont, opportunist and oncobacterium. Nature Rev Microbiol 2019;17(3):156-66.

2. Bolstad Al, Jensen HB, Bakken V. Taxonomy, Biology, and Periodontal Aspects of Fusobacterium Nucleatum. Vol 9; 1996.
3. Epaulard O, Brion JP, Stahl JP, Colombe B, Maurin M. The changing pattern of fusobacterium infections in humans: Recent experience with fusobacterium bacteraemia. Clin Microbiol Infect 2006;12(2):178-81.

4. Williams MD, Kerber CA, Tergin HF. Unusual presentation of lemierre's syndrome due to Fusobacterium nucleatum. I Clin Microbiol 2003;41(7):3445-3448.

5. AM Bourgault, F Lamothe, P Dolce, L Saint-Jean, P Saint-Antoine. Fusobacterium bacteremia: clinical experience with 40 cases. Clin Infectious Dis 1997:25(Suppl. 2); $5181-5183$

6. Candoni A, Fili C, Trevisan R, Silvestri F, Fanin R. Fusobacterium nucleatum: $A$ rare cause of bacteremia in neutropenic patients with leukemia and lymphoma. Clin Microbiol Infect 2003;9(11):1112-5.

7. Sharifipour E, Shams S, Esmkhani M. Evaluation of bacterial co-infections of the respiratory tract in COVID-19 patients admitted to ICU. BMC Infect Dis 2020;20(1):646.

8. Hughes S, Troise O, Donaldson H, Mughal N, Moore LSP. Bacterial and fungal coinfection among hospitalized patients with COVID-19: a retrospective cohort study in a UK secondary-care setting. Clin Microbiol Infect 2020;26(10):13959.

9. Wolff L, Martiny D, Deyi VYM, Maillart E, Clevenbergh P, Dauby N. COVID-19-Associated Fusobacterium nucleatum Bacteremia, Belgium . Emerg Infect Dis 2021;27(3).

10. Repper DC, Arrieta AC, Cook JE, Renella P. A Case of lemierre syndrome in the era of COVID-19: All that glitters is not gold. Pediatr Infect Dis J Published online 2020:E445-E447.

11. Irvem A, Bedir M, Yoğurtçuoğlu-Eren EE, Bağcl-Türkmen S, Kıran G. Fusobacterium nucleatum'un neden olduğu koryoamniyonit: bir olgu sunumu. Klimik 2018:31(1);74-6.

12. Langford $B$ J, So $M$, Raybardhan S. Bacterial co-infection and secondary infection in patients with COVID-19: a living rapid review and meta-analysis. Clin Microbiol Infect 2020;26(12):1622-9.

13. Sepulveda J, Westblade LF, Whittier S. Bacteremia and blood culture utilization during covid-19 surge in New York City. J Clin Microbiol 2020;58(8).

\section{Yazıșma Adresi/Address for Correspondence}

Dr. Mehmet Serhat BIRENGEL

Ankara Üniversitesi Tıp Fakültesi,

İnfeksiyon Hastalıkları ve

Klinik Mikrobiyoloji Anabilim Dal,,

Ankara-Türkiye

E-posta: serhatbirengel@gmail.com 